\title{
The Implementation of the "Authorized OECD Approach" under German Law and its Relation to Already Existing Double Tax Conventions - Can the "Authorized OECD Approach" be Applied Retrospectively?
}

\section{Rabea Katharina Lingier}

\begin{abstract}
After the implementation of the Authorized OECD Approach (AOA) in Article 7 of the OECD Model Tax Convention, Germany also implemented this approach for the attribution of profits to permanent establishments (PEs) in national tax law. Due to existing uncertainties concerning the application of the AOA, the attribution of profits to PEs has become increasingly complex. It is even doubted, whether the German Foreign Tax Act was the correct tax act to implement the $A O A$ in and whether it was necessary to implement the AOA at all. An important question arising in this context is, whether the $A O A$ can be applied to already existing Double Tax Conventions with retrospective effect. Even though there is no legal basis in German law for this, there are still some questions left open, which should be answered by the legislator.
\end{abstract}

\section{Introduction}

The attribution of profits to PEs has become increasingly complex during the last years and it is expected to become even more complex in the 
future. ${ }^{1}$ This increased complexity can, inter alia, be attributed to the introduction of the "Authorized OECD Approach" in 2010. The AOA is a method for attributing profits to PEs in two steps and was meant to facilitate the international profit attribution to PEs. ${ }^{2}$ The intention of the OECD was to achieve a higher level of legal certainty and to harmonize the differing rules on profit attribution to PEs in the OECD countries. Another reason for the implementation of the AOA brought forward by the OECD was the avoidance of double taxation and double non-taxation arising from divergent rules on profit allocations to PEs. ${ }^{3}$ However, the AOA was highly disputed and it is noticeable that it is not accepted as an appropriate approach to attribute profits to PEs in the United Nations Model Double Taxation Convention (DTC). Even the OECD accepted the introduction of this approach by majority vote only. ${ }^{4}$ This implies that there is no international consensus on the application of the AOA. While it is expected to result in problems in international co-operations, it is also expected to lead to complications in national law since it is built up on fictions that are difficult to determine for tax law practitioners. ${ }^{5}$

The AOA has been implemented in the German Foreign Tax Act in $2013 .^{6}$ The existence of the new approach has resulted in uncertainties on how to apply national law in the context of attributing profits to PEs

1 Prof. Dr. Alexander Hemmelrath, Dipl.-Jur. Philipp Kepper; "Die Bedeutung des Authorized OECD Approach (AOA) für die deutsche Abkommenspraxis". IStR 2013, pp.37-42, p.42.

2 Prof. Dr. Holger Kahle, Jörg Mödinger; "Die Neufassung des Art. 7 OECD-MA im Rahmen der Aktualisierung des OECD-MA 2010". IStR 2010, pp.757-763, p.757.

3 Dr. Arne Schnitger; "Comments on the Klaus Vogel Lecture Problems arising under Domestic Tax Law due to the Introduction of the Authorized OECD Approach". Bulletin for International Taxation April / May 2013, pp.211-215, pp.211-212.

4 Prof. Dr. Dr. h.c. Franz Wassermeyer; "Die abkommensrechtliche Aufteilung von Unternehmensgewinnen zwischen den beteiligten Vertragsstaaten". IStR 2012, pp.277-282, p.282.

5 Prof. Dr. Alexander Hemmelrath, Dipl.-Jur. Philipp Kepper; "Die Bedeutung des Authorized OECD Approach (AOA) für die deutsche Abkommenspraxis". IStR 2013, pp.37-42, p.42.

6 German Foreign Tax Act -Außensteuergesetz vom 8. September 1972, das zuletzt durch Artikel 6 des Gesetzes vom 26. Juni 2013 (BGBI. I S. 1809) geändert worden ist. 
in cross-border situations. ${ }^{7}$ An important question which arises is how the AOA is related to DTCs that were concluded before 2010. Most of the DTCs Germany has concluded up until now do not include the AOA yet. ${ }^{8}$ Therefore, it is important to analyze, whether the AOA can be applied to already existing DTCs with retrospective effect.

This article will address the application of the AOA under German national law. It is analyzed, whether the implementation of the AOA is necessary to harmonize the profit attribution to PEs under German law. The article also includes a section on DTC law and the retrospective application of the AOA to already existing DTCs, not including the AOA. Concluding remarks and future prospects can be found at the end of this article.

\section{The "Authorized OECD Approach" in the OECD Model Tax Convention}

\subsection{AOA - the new 2010 version of Article 7 OECD Model Tax Convention}

The AOA, which is also called the functional separate entity approach, has been introduced to the 2010 OECD Model Tax Convention (OECD $M C$ ) in order to achieve a uniform rule on the profit attribution to PEs in the OECD countries. This was expected to avoid double taxation as well as double non-taxation, which the OECD intends to achieve under the OECD MC. ${ }^{9}$

According to the AOA, PEs are considered to be fictitious functional separate entities. Under the AOA, the profits that have to be attributed to a PE are "the profits the PE would have earned at arm's length, particularly in its relations with related parties, as if it were a separate and independent legal entity engaged in the same or similar activities

7 Prof. Dr. Alexander Hemmelrath, Dipl.-Jur. Philipp Kepper; „Die Bedeutung des Authorized OECD Approach (AOA) für die deutsche Abkommenspraxis". IStR 2013, pp.37-42, p.42.

8 Prof. Dr. Dr. h.c. Franz Wassermeyer; „Die abkommensrechtliche Aufteilung von Unternehmensgewinnen zwischen den beteiligten Vertragsstaaten". IStR 2012, pp.277-282, p.277.

9 Dr. Arne Schnitger; "Comments on the Klaus Vogel Lecture Problems arising under Domestic Tax Law due to the Introduction of the Authorized OECD Approach". Bulletin for International Taxation April / May 2013, pp.211-215, pp.211-212. 
under the same or similar conditions, taking into account the functions performed, assets used and risks assumed by the enterprise through the PE and through the other parts of the enterprise." ${ }^{10}$

Therefore, Article 7 of the OECD Model Tax Convention as well as the Commentary to the Model Tax Convention were amended in 2010 in order to introduce the intended changes. ${ }^{11}$ Under the AOA, the profit attribution to PEs is divided into a two-step procedure:

In the first step, a functional and factual analysis of the PE has to be conducted, which comprises the attribution of significant people functions, assets and risks. The attribution of functions and risks can never be split, the primary principle being that risks always follow functions. The capital that has to be attributed to the PE can be based on these findings. This can either be done according to a third party comparison (thin capitalization) or alternatively, the existing equity can be split according to the asset and risk allocation (capital allocation approach). ${ }^{12}$

In the second step, the fictitious dealings between the PE and the parent company are determined in order to evaluate, whether prices in intra-company-transactions have been set in accordance with the arm's length principle. The OECD transfer pricing guidelines ${ }^{13}$ have to be applied in this step. ${ }^{14}$

If states agree to include the AOA in their bilateral tax conventions, they are both obliged to apply the AOA according to Article 7 OECD MC, whereas Article 23 OECD MC obliges states to provide taxpayers relief from double taxation. States are free to apply either the exemption or the credit method to grant relief from international double taxation. ${ }^{15}$

10 Article 7 OECD Model Tax Convention on Income and on Capital 2010-2012.

11 Dr. Xaver Ditz, Dr. Sven-Eric Bärsch; "Gewinnabgrenzung bei Vertreterbetriebsstätten nach dem AOA- ein Plädoyer für die Nullsummentheorie". IStR 2013, pp.411-417, p.411.

12 Prof. Dr. Holger Kahle, Jörg Mödinger; "Die Neufassung des Art. 7 OECD-MA im Rahmen der Aktualisierung des OECD-MA 2010". IStR 2010, pp.757-763, pp. 759-761.

13 OECD Transfer Pricing Guidelines for Multinational Enterprises and Tax Administrations 1995 - 2013.

14 Ibid., pp. 761-762.

$15 \mathrm{Dr}$. Arne Schnitger; "Änderungen des §1 AStG und Umsetzung des AOA durch das JStG 2013". IStR 2012, pp.633-645, p.634. 


\subsection{Differences between the 2008 and 2010 approaches for profit attribution to PEs.}

In this section the differences between the old and the new approach for the profit attribution to PEs will be described.

Article 7 OECD MC 2008 / 2010 version. ${ }^{16}$

\begin{tabular}{|c|c|c|}
\hline & OECD MC $2008^{17}$ & OECD MC $2010^{18}$ \\
\hline Para. 1 & $\begin{array}{l}\text { 1. The profits of an enterprise of a } \\
\text { Contracting State shall be taxable } \\
\text { only in that State unless the } \\
\text { enterprise carries on business in the } \\
\text { other Contracting State through a } \\
\text { permanent establishment situated } \\
\text { therein. If the enterprise carries on } \\
\text { business as aforesaid, the profits of } \\
\text { the enterprise may be taxed in the } \\
\text { other State but only so much of } \\
\text { them as is attributable to that } \\
\text { permanent establishment. }\end{array}$ & $\begin{array}{l}\text { 1. Profits of an enterprise of a } \\
\text { Contracting State shall be taxable } \\
\text { only in that State unless the } \\
\text { enterprise carries on business in } \\
\text { the other Contracting State } \\
\text { through a permanent } \\
\text { establishment situated therein. If } \\
\text { the enterprise carries on business } \\
\text { as aforesaid, the profits that are } \\
\text { attributable to the permanent } \\
\text { establishment in accordance with } \\
\text { the provisions of paragraph } 2 \text { may } \\
\text { be taxed in that other State. }\end{array}$ \\
\hline Para. 2 & $\begin{array}{l}\text { 2. Subject to the provisions of } \\
\text { paragraph } 3 \text {, where an enterprise of } \\
\text { a Contracting State carries on } \\
\text { business in the other Contracting } \\
\text { State through a permanent } \\
\text { establishment situated therein, } \\
\text { there shall in each Contracting State } \\
\text { be attributed to that permanent } \\
\text { establishment the profits which it } \\
\text { might be expected to make if it were } \\
\text { a distinct and separate enterprise } \\
\text { engaged in the same or similar } \\
\text { activities under the same or similar } \\
\text { conditions and dealing wholly } \\
\text { independently with the enterprise of } \\
\text { which it is a permanent } \\
\text { establishment. }\end{array}$ & $\begin{array}{l}\text { 2. For the purposes of this Article } \\
\text { and Article [23 A] [23B], the } \\
\text { profits that are attributable in each } \\
\text { contracting State to the permanent } \\
\text { establishment referred to in } \\
\text { paragraph } 1 \text { are the profits it might } \\
\text { be expected to make, in particular } \\
\text { in its dealings with other parts of } \\
\text { the enterprise, if it were a separate } \\
\text { and independent enterprise } \\
\text { engaged in the same or similar } \\
\text { activities under the same or similar } \\
\text { conditions, taking into account the } \\
\text { functions performed, assets used } \\
\text { and risks assumed by the } \\
\text { enterprise through the permanent } \\
\text { establishment and through the } \\
\text { other parts of the enterprise. }\end{array}$ \\
\hline Para. 3 & $\begin{array}{l}\text { 3. In determining the profits of a } \\
\text { permanent establishment, there } \\
\text { shall be allowed as deductions } \\
\text { expenses which are incurred for the }\end{array}$ & $\begin{array}{l}\text { 3. Where, in accordance with } \\
\text { paragraph } 2 \text {, a Contracting State } \\
\text { adjusts the profits that are } \\
\text { attributable to a permanent }\end{array}$ \\
\hline
\end{tabular}

16 Differences in the two versions have been marked in italics.

17 OECD Model Tax Convention on Income and Capital 2008.

18 OECD Model Tax Convention on Income and Capital 2010. 


\begin{tabular}{|c|c|c|}
\hline & $\begin{array}{l}\text { purposes of the permanent } \\
\text { establishment, including executive } \\
\text { and general administrative expenses } \\
\text { so incurred, whether in the State in } \\
\text { which the permanent establishment } \\
\text { is situated or elsewhere. }\end{array}$ & $\begin{array}{l}\text { establishment of an enterprise of } \\
\text { one of the Contracting States and } \\
\text { taxes accordingly profits of the } \\
\text { enterprise that have been charged } \\
\text { to tax in the other State, the other } \\
\text { State shall, to the extent necessary } \\
\text { to eliminate double taxation on } \\
\text { these profits, make an appropriate } \\
\text { adjustment to the amount of the } \\
\text { tax charged on those profits. In } \\
\text { determining such adjustment, the } \\
\text { competent authorities of the } \\
\text { Contracting States shall if } \\
\text { necessary consult each other. }\end{array}$ \\
\hline Para. 4 & $\begin{array}{l}\text { 4. Insofar as it has been customary } \\
\text { in a Contracting State to determine } \\
\text { the profits to be attributed to a } \\
\text { permanent establishment on the } \\
\text { basis of an apportionment of the } \\
\text { total profits of the enterprise to its } \\
\text { various parts, nothing in paragraph } \\
2 \text { shall preclude that Contracting } \\
\text { State from determining the profits } \\
\text { to be taxed by such an } \\
\text { apportionment as may be } \\
\text { customary; the method of } \\
\text { apportionment adopted shall, } \\
\text { however, be such that the result } \\
\text { shall be in accordance with the } \\
\text { principles contained in this Article. }\end{array}$ & $\begin{array}{l}\text { 4. Where profits include items of } \\
\text { income which are dealt with } \\
\text { separately in other Articles of this } \\
\text { Convention, then the provisions of } \\
\text { those Articles shall not be affected } \\
\text { by the provisions of this Article. }\end{array}$ \\
\hline Para. 5 & $\begin{array}{l}\text { 5. No profits shall be attributed to a } \\
\text { permanent establishment by reason } \\
\text { of the mere purchase by that } \\
\text { permanent establishment of goods } \\
\text { or merchandise for the enterprise. }\end{array}$ & \\
\hline Para. 6 & $\begin{array}{l}\text { 6. For the purposes of the preceding } \\
\text { paragraphs, the profits to be } \\
\text { attributed to the permanent } \\
\text { establishment shall be determined } \\
\text { by the same method year by year } \\
\text { unless there is good and sufficient } \\
\text { reason to the contrary. }\end{array}$ & \\
\hline Para. 7 & $\begin{array}{l}\text { 7. Where profits include items of } \\
\text { income which are dealt with } \\
\text { separately in other Articles of this } \\
\text { Convention, then the provisions of } \\
\text { those Articles shall not be affected } \\
\text { by the provisions of this Article. }\end{array}$ & \\
\hline
\end{tabular}

As can be derived from this table, some changes made to the 2010 version of the OECD MC are merely based on a new wording. Furthermore, sub-paragraphs (4) to (6) have been deleted in the new 
version of the Model Tax Convention. This means that the AOA is a more restricted version of the 2008 approach on attributing profits to PEs.

The largest change, however, concerns the method of attributing profits to a PE. Under the 2008 version it was possible to apply the indirect method, whereas this is no longer an option under the 2010 OECD MC. The AOA prohibits the application of the indirect method so to say. As described above, the AOA can also be referred to as the "functionally separate entity approach". This means that the PE will be treated as if it was a separate entity and fictitious independence will be assumed. Under the old approach, however, although it is also tried to view the PE as isolated from the remaining part of the enterprise, profits only arise in transactions with third parties. The idea behind this approach is to identify the relevant business activities of the PE. Based on this determination, an appropriate proportion of the enterprise's profits / losses as a whole will be attributed to the PE. Although this might first create the impression that the differences are only of a minor nature, the application of the two different methods might result in different practical outcomes eventually. Under the indirect method (2008) the profit / loss making position of the PE will be determined by the fact, whether the enterprise as a whole is making a profit or a loss. This means that the PE cannot make a profit when the enterprise as a whole made losses. This is due to the fact that the PE will always be attributed a proportion of the profits/ losses of the enterprise as a whole. Under the functionally separate entity approach this is not necessarily the case. Accordingly, under this approach, the PE can make a profit or a loss even when the enterprise as a whole is in the opposite situation. This can be explained by the fact that the PE is deemed to be independent from the rest of the enterprise. Furthermore, timing differences might arise. Under the functionally separate entity approach, intra-company transactions will already be "taxable" although there has not been a transaction with a third party yet. Intra-company transactions are treated as fictitious dealings, meaning that they are subject to taxation. Under the indirect method, however, it is assumed that profits can only arise in transactions with third parties, meaning that taxation will probably take place at a later point in time under this approach, namely when goods / services are eventually transferred to the third party.

According to the 2008 approach a PE can also make use of a right of deduction. This can also be of relevance for the profitability of the PE and the enterprise as a whole. This can be illustrated with the example of interest deductions. Under the indirect method, it is possible for the PE to deduct interest expenses when they are incurred for the purposes 
of the PE. This, however, is no longer possible under the AOA, meaning that the $P E$ will be placed in a less advantageous position under the new version of Article 7 OECD MC.

Accordingly, it can be seen that there exist large differences between the old and the new version of Article 7 OECD MC. It is doubtful, whether it was reasonable to delete the indirect method from the new version of Article 7 OECD MC. Although it might seem feasible in theory to treat the PE as a functionally separate entity, this is expected to be difficult in practice. Due to the fact that the AOA is based on fictitious dealings that have to be assumed between the parties, difficulties in determining the taxable intra-group transactions might arise. Therefore, it seems as if it would be reasonable to still apply the indirect/ apportionment method in certain cases, in which it would be too administratively burdensome to apply the functionally separate entity approach. The indirect method might facilitate the attribution of profits to PEs in practice, although it reflects economic reality less accurately. Therefore, it might be reasonable to reconsider, whether it was necessary and useful to abolish the indirect method under the new version of Article 7 OECD MC.

\section{The Authorized OECD Approach in German Tax Practice}

This section contains an analysis and an evaluation of the implementation of the AOA under German national law.

\subsection{The implementation of the AOA under German law}

Although the German Ministry of Finance strived for the introduction of the AOA into German national law in 2012 already, the AOA could only be adopted in June 2013 due to the resistance of the German Federal Assembly, which did not consent to relevant legislative proposals in the annual tax law $2013^{19}$, also referring to the AOA, in late 2012 and early 2013. The legislation could only be published in the Federal Law Gazette on 29 June, 2013, thereby implementing Article 7 of the OECD Model

19 Entwurf eines Jahressteuergesetzes 2013 vom 10.04.2013, BT-Drs. $17 / 13033$. 
Tax Convention and the respective Commentary to the Convention into German law. ${ }^{20}$

The AOA has been implemented in $\S 1$ para. 5 German Foreign Tax Act. ${ }^{21}$ Here, the relationship between the mother company and its PE is addressed. As under the OECD approach, the PE is deemed to be a separate legal entity, unless it is otherwise required according to international legal standards. ${ }^{22}$ The AOA entered into force as of the financial years after 31 December, $2012 .{ }^{23}$ The first DTCs including the AOA have been concluded with Liechtenstein and the Netherlands. ${ }^{24}$ However, it is noticeable that Germany was still negotiating DTCs applying the old mechanisms of attributing profits to PEs in 2010 and 2011. ${ }^{25} \S 1$ para. 6 German Foreign Tax Act allows the Federal Ministry of Finance(BFM) to introduce a regulation addressing practical issues related to the application of the AOA under national law. The BFM came up with a regulation proposal, called Betriebsstättengewinnaufteilungsverordnung ${ }^{26}$ on 5th August, $2013 .{ }^{27}$ The Amtshilferichtlinie-Umsetzungsgesetz transforms the AOA into German national law and extends the application of $\S 1$ AStG to PEs. ${ }^{28}$ As in Article 7 of the OECD Model Tax Convention, a two-step approach has been implemented in $\S 1$ para. 5 sentences 3 and 4 AStG. In the first step, according to $\S 1$ para. 5 sentence 3 AStG, significant people functions as well as assets and risks are attributed to the PE. Based on this, the endowment capital of the PE has to be determined. In the

20 Johannes Schimmer; "Germany: Transfer Pricing and Customs Valuation". IBFD, 2013, pp. 1-41, pp. 4-5.

21 Außensteuergesetz vom 8. September 1972, das zuletzt durch Artikel 6 des Gesetzes vom 26. Juni 2013 (BGBI. I S. 1809) geändert worden ist.

22 Pohl, "VI. Gewinnabgrenzung bei Betriebsstätten (Abs. 5)", in: Blümich; AstG $\S 1$ Berichtigung von Einkünften. 121st edition, München: Beck, 2014.

$23 \S 21$ Abs. 20 AStG.

24 Axel Neumann; "Das Verhältnis von $\S 1$ Abs. 5 AStG zu den deutschen Doppelbesteuerungsabkommen". IStR 2013, pp.573-577, p. 574.

25 Prof. Dr. Dr. h.c. Franz Wassermeyer; „Die abkommensrechtliche Aufteilung von Unternehmensgewinnen zwischen den beteiligten Vertragsstaaten". IStR 2012, pp.277-282, p.282.

26 AmtshilfeRLUmsG i.d.F. des Bundestagsbeschlusses Br-Drs. 477/13.

27 Dr. Ernst-August Baldamus; "Neues zur

Betriebsstättengewinnermittlung". IStR 2012, pp.317-324, p.319.

28 AmtshilfeRLUmsG i.d.F. des Bundestagsbeschlusses Br-Drs. 477/13. 
second step, according to $\S 1$ para. 5 sentence 4 AStG intra-company dealings are assumed and it is to be analyzed, whether the arm's length principle had been adhered to in such dealings. According to $\S 1$ para. 5 sentence 5 AStG, the AOA also has to be applied to agency PEs. ${ }^{29}$ The above described two-step approach was already included in the OECD Report on the Attribution of Profits to Permanent Establishments $2008^{30}$. Parts of this report, which were considered to be comptatible with the OECD Model Tax Convention and the Commentary to the OECD Model Tax Convention, were implemented in the 2008 Commentary on Article 7 of the OECD Model Tax Convention already. As a result, it was believed that the AOA could be applied to DTCs concluded after $2008 .^{31}$ In 2010, Article 7 of the OECD Model Tax Convention as well as the Commentary were completetely amended. ${ }^{32}$ Whether the AOA could indeed be applied as of 2008 already will be discussed in the next section of this article.

It was criticized that it was not appropriate to solely base the application of the AOA on $\S 1$ AStG, which is an income correction rule. This is due to the fact that the profit attribution to a PE is covered under the ${ }^{33}$ profit determination rules in the sense of $\S 4$ para.1 German Income Tax Act (EStG) ${ }^{34}$, which deals with cases of inbound and outbound PEs. §4 EStG regulates how to determine profits. In this paragraph it is laid down what is and what is not to be taken into account to determine the profit, as well as when the profit has to be declared. It is perceived to be the basic rule for profit determination in the EStG. Accordingly, it would have been necessary to also implement the AOA in the EStG due to the fact that the AOA also concerns profit allocation to PEs. Although the analysis of the profit attribution to a PE

29 Dr. Dirk Brüninghaus, "Einkunftsabgrenzung bei Betriebsstätten und Personengesellschaften", in: Vögele / Borstell / Engler et al.; Verrechnungspreise. 3rd edition, München: Beck, 2011, Rn 72-77.

30 OECD Report on the Attribution of Profits to Permanent Establishments - 17 July 2008.

31 Dr. Xaver Ditz, Dr. Sven-Eric Bärsch; „Gewinnabgrenzung bei Vertreterbetriebsstätten nach dem AOA- ein Plädoyer für die Nullsummentheorie". IStR 2013, pp.411-417, p.411.

32 OECD Model Tax Convention on Income and on Capital 2010-2012.

33 "Tatbestand". No translation available. It means that it is covered / it is a relevant criterion for the profit determination under §4 EStG.

34 Einkommenssteuergestz in der Fassung der Bekanntmachung vom 8. Oktober 2009 (BGBI. I S. 3366, 3862), das zuletzt durch Artikel 11 des Gesetzes vom 18. Dezember 2013 (BGBI. I S. 4318) geändert worden ist. 
can result in an income correction eventually, it should not be easily assumed that the profit allocation is to be corrected in every case. This implies that it was not sufficient / correct to implement the AOA as an income correction rule under $\S 1$ AStG only.

At the same time it is perceived that the implementation of the AOA in national law is more beneficial for the tax administrations than for the taxpayers. Whereas the attribution of income can be corrected under the AStG, the EStG serves to determine the income of legal entities. ${ }^{35}$ Therefore, it would have been more beneficial for taxpayers, when the AOA would have been implemented in the EStG as well, since this approach would not automatically assume that the profit allocation to PEs has to be corrected. Instead there would be the chance to neutrally allocate/ determine the profits to PEs in a first instance.

It seems as if the German legislator should reconsider the place of implementation of the AOA and also amend the corresponding articles in the EStG.

\subsection{The AOA as a harmonization instrument in Germany (Is the AOA necessary to harmonize the profit attribution to PEs?)}

According to the legislator, it was necessary to implement the AOA into German national law in order to close gaps in the existing legal system due to the fact that there were no explicit rules in the German Income Tax Act (EStG), the German Corporate Income Tax Act (KStG) and the German Foreign Tax Act (AStG). Additionally, the implementation of the AOA was perceived to be required based on constitutional law. The necessity to introduce the AOA arose from the required ability to tax the right part of the profits at the level of the source state. However, it is doubtful, whether this indeed is a valid reason for the implementation of the AOA. Under German law a distinction has to be made between unlimited and limited tax liability of taxable persons.

According to most scholars there was no necessity to introduce a new rule for persons with limited tax liability. They claim that the determination of profits for tax purposes can be exercised in accordance with $\S \S 49$ and 50 EStG. $\S 49$ EStG deals with profit determination in cases of limited tax liability. It covers different types of income a taxable person can obtain. \$49 para.2 EStG prescribes an isolated

35 Axel Neumann; „Das Verhältnis von §1 Abs. 5 AStG zu den deutschen Doppelbesteuerungsabkommen". IStR 2013, pp.573-577, p.576. 
approach for domestic and foreign sourced income. §50 EStG addresses withholding methods in cases of limited tax liability for limited categories of income. It is even possible to allocate assets to the relevant business area under $\S \S 4 \mathrm{ff}$. EStG. This attribution is limited/ restricted by national law as well as under the respective DTCs concluded by Germany with other states. Therefore, the implementation of the AOA in $\S 1$ para.5 AStG proves not to be necessary for taxable persons subject to limited tax liability.

In case of persons subject to unlimited tax liability, there indeed exists a gap concerning the profit attribution to PEs. The profit of a person subject to unlimited tax liability has to be determined in accordance with $\S \S 4 \mathrm{ff}$. EStG. This rule could only be disregarded in case the PE would be considered a separate legal entity. However, this would contradict the worldwide income taxation system applied for persons subject to limited tax liability as well as certain accounting rules under the German Commercial Code ${ }^{36}$. Accordingly, in the absence of a rule like $\S 50$ EStG (withholding methods), it is difficult to determine the profit of a PE and the situation of unlimited and limited tax liability is not comparable in this sense. This gap in the law can be closed by including the new version of Article 7 of the OECD Model Tax Conventions in DTCs with other states since the AOA would also cover this gap in German tax law. It is important that both states, that concluded a respective DTC with each other (Germany and the other state), make use of the same method for attributing profits to PEs. Otherwise the risk of double taxation increases. The mechanism of corrections and the respective counter-corrections according to the AOA under German law can only be applied when both states agree to apply the AOA. If this is the case, individual profit attribution rules can be agreed upon between Germany and the other state, meaning that Article 7 can compensate for the missing rules on the profit attribution to PEs in case a person is subject to unlimited tax liability. Accordingly, it can be concluded that there only is a gap for persons subject to unlimited tax liability in states with which Germany did not conclude a DTC, including Article 7 of the OECD Model Tax Convention. Therefore, doubts can be expressed, whether it was really necessary to implement

36 Handelsgesetzbuch in der im Bundesgesetzblatt Teil III, Gliederungsnummer 4100-1, veröffentlichten bereinigten Fassung, das zuletzt durch Artikel 1 des Gesetzes vom 4. Oktober 2013 (BGBI. I S. 3746) geändert worden ist. 
the AOA in order to harmonize the rules on profit attribution to PEs or whether this could have been done in a different/ less complex way. ${ }^{37}$

\subsection{DTC law and the retrospective application of the AOA to already existing DTCs (Not including the AOA)}

The OECD has made clear that the AOA can only be applied restrictedly, the wording of existing DTCs being the cornerstone for the interpretation of DTCs as well as Article 7 OECD Model Tax Convention. However, according to the OECD Committee of Fiscal Affairs, amendments and inserts to the Commentary on the OECD Model Tax Convention, which do not result from an amendment of an Article in the OECD Model Tax Convention, can nevertheless be taken into account when already existing DTCs have to be analyzed. They base their reasoning on the fact that those amendments reflect the intentions of the states that agreed to them, leading them to the conclusion that amendments can be applied in certain situations and contexts. According to this view, the current changes on the AOA would be binding even in case of already existing DTCs due to the clarifying nature of the amendments. However, the assumption of the OECD Committee of Fiscal Affairs is denied under international law as well as under German law. The OECD has not been given legislative power, meaning that the Commentary cannot be of a binding nature. Furthermore, it is believed that it would not be appropriate to make changes in the Commentary on the OECD Model Tax Convention binding upon the states, taking into account the fact that the Commentary is updated regularly. According to this approach, the AOA could only be applied to already existing DTCs, in case the internal power of persuasion is sufficiently high to prove that it was intended to actually apply the AOA in relations between the two states concerned. Besides that, states are free to always conclude additional agreements concerning the application of the AOA, as was done between Germany and the USA, for example. ${ }^{38}$

37 Axel Neumann; "Das Verhältnis von §1 Abs. 5 AStG zu den deutschen Doppelbesteuerungsabkommen". IStR 2013, pp.573-577, pp. 575-577.

38 Dr. Dirk Brüninghaus, "Einkunftsabgrenzung bei Betriebsstätten und Personengesellschaften", in: Vögele / Borstell / Engler et al.; Verrechnungspreise. 3rd edition, München: Beck, 2011, Rn 72-77. 
In Germany, most of the DTCs that Germany concluded, do not contain the new AOA yet. ${ }^{39}$ This even holds true for DTCs that have been negotiated and concluded after the AOA has been implemented into $\S 1$ AStG. For example, Germany recently concluded DTCs with China, Costa Rica and the Philippines, which all do not contain the new version of Article 7 yet.

Therefore, it is a relevant question to analyze, whether it is possible to apply the AOA with retrospective effect. In this context, generally, no distinction has been made between situations in which a DTC exists, and situations, in which no DTC exists between Germany and the other state concerned. In case there is no common understanding of how to attribute profits to parent companies and their PEs, double taxation can occur, which should be avoided. ${ }^{40}$ Besides that, it should also be questioned, how it is possible for Germany to still conclude DTCs that do not contain the AOA, even though this approach has already been implemented in national law. This could result in the assumption / belief that $\S 1$ para.5 AStG does not only specifically refer to the new version of Article 7, but instead also still accepts the old method of attributing profits to PEs. That would imply that business/ economic reasons prevail over the legal basis in $\S 1$ para.5 AStG, meaning that Germany does not want to risk that the other negotiating party would refuse to conclude the DTC because Germany insists on implementing the AOA. This seems to be an open question, which remains to be solved in the future.

Under German law, §1 para. 5 sentence 8 AStG addresses the situation in which the DTC concluded between Germany and the other country does not contain the AOA yet. Generally, it is considered to prevent the unilateral extension of taxing rights of Germany. This paragraph gives precedence to existing DTC law, meaning that applying the AOA could constitute a treaty override when the other state applies another method to attribute profits to the PE under the existing DTC. In order to be able to apply $\S 1$ para. 5 sentence 8 AStG, it has to be proven that the other state attributes profits to the PE according to the method under the already existing DTC, implying that the application of the AOA would lead to double taxation. However, it has not been specified which evidence is required in order to stress that the simultaneous application of the already existing DTC and the AOA would actually result in double

39 Prof. Dr. Dr. h.c. Franz Wassermeyer; "Die abkommensrechtliche Aufteilung von Unternehmensgewinnen zwischen den beteiligten Vertragsstaaten". IStR 2012, pp.277-282, p.277.

40 Dr. Xaver Ditz, Dr. Carsten Quilitzsch; "Die Änderungen im AStG durch das AmtshilfeRLUmsG - Quo vadis Außensteuergesetz?". DStR 2013, pp.1917-1923, p.1919. 
taxation for the taxpayer. ${ }^{41} \mathrm{EU}$ law requires that the burden to produce valid evidence according to German law may not be unreasonably high or discriminatory. ${ }^{42}$ Because of these uncertainties, it can be expected that the application of the AOA leads to a more complicated determination of profit attribution to PEs.

Furthermore, the law does not define situations in which double taxation occurs, meaning that it is uncertain, whether it only covers double taxation in the strict sense or whether the double allocation of profits is already sufficient. In case double taxation occurs, the taxable person has to claim that there exists a contradiction in the simultaneous application of the DTC and the AOA. In a next step, the tax administration has to evaluate the claim brought forward by the taxpayer. ${ }^{43}$ The tax administration does not accept cases, in which double taxation arises as a result of a different interpretation of the DTC since such cases have to be solved under mutual agreement procedures. Only cases that arise based on the existence of differences in the legal systems concerned will be considered by the tax administration. The taxpayer has to prove that the other state exercises its taxing powers in accordance with the provisions in the DTC concerned. The most important fact in this context is that this state is not applying the AOA in order to attribute profits to the PE. This could also be challenged under EU law because it implies that there is a higher administrative burden of proof for PEs than for other legal entities / forms that are not covered by the profit attribution under the AOA. ${ }^{44}$

Accordingly, the new version of Article 7 of the OECD Model Tax Convention 2010 should only be applied, when the states concerned agree on the application of this new version.

However, the content of the report on the attribution of profits to PEs has been included in paragraphs 17 and 18 of the 2008 Commentary on the OECD Model Tax Convention already. ${ }^{45}$ This has been done in order

41 Ibid., p.1919.

42 Dr. Xaver Ditz, Dr. Carsten Quilitzsch; „Die Änderungen im AStG durch das AmtshilfeRLUmsG - Quo vadis Außensteuergesetz?". DStR 2013, pp.1917-1920.

43 Prof. Dr. Alexander Hemmelrath, Dipl.-Jur. Philipp Kepper; „Die Bedeutung des Authorized OECD Approach (AOA) für die deutsche Abkommenspraxis". IStR 2013, pp.37-42.

44 Dr. Dirk Brüninghaus, "Einkunftsabgrenzung bei Betriebsstätten und Personengesellschaften", in: Vögele / Borstell / Engler et al.; Verrechnungspreise. 3rd edition, München: Beck, 2011, Rn 72-77. 45 OECD Model Tax Convention on Income and on Capital Commentary 2008. 
for states to be able to apply the AOA to already existing DTCs. However, the Commentary is not binding upon the parties in that sense, meaning that it only constitutes an opinion that can be taken into account for the interpretation of a DTC. Therefore, the DTC interpretation concerning Article 7 is limited by German DTC law as well as international law. Although the Commentary on the OECD Model Tax Convention has an interpretative value according to Art. 31 para. 4 and Article 32 of the Vienna Convention ${ }^{46}$, the static approach of interpretation for DTCs is to be preferred in Germany. This means that already existing DTCs can only be interpreted according to the principles contained in the Commentary on the OECD Model Tax Convention at the time the DTC concerned was concluded. Only then, the intentions of the parties according to which the DTC has been concluded, can be guaranteed. ${ }^{47}$ German constitutional law requires that the German Parliament together with the German Federal Council provide for a Decree which would allow to take into account amendments to already existing DTCs. However, this has not happened until today. ${ }^{48}$ Accordingly, the AOA can only be applied, when both parties indicate the intention that they wish to apply the new version of Article 7 of the OECD Model Tax Convention in their bilateral co-operations. ${ }^{49}$ This has also been made clear in German case law, stressing that the Commentary on the OECD Model Tax Convention only has to be taken into account in the version in which it existed at the time the DTC was concluded. ${ }^{50}$

The only question that remains open for discussion is what will happen to DTCs that have been concluded between Germany and other states after the changes to the 2008 Commentary on the OECD Model Tax Convention have been made public. One possible approach is that from

46 Vienna Convention on the Law of Treaties, 1155 U.N.T.S. 331, 8 I.L.M. 679.

47 Prof. Dr. Alexander Hemmelrath, Dipl.-Jur. Philipp Kepper; "Die Bedeutung des Authorized OECD Approach ( $A O A$ ) für die deutsche Abkommenspraxis". IStR 2013, pp.39-40.

48 Grundgesetz für die Bundesrepublik Deutschland in der im Bundesgesetzblatt Teil III, Gliederungsnummer 100-1, veröffentlichten bereinigten Fassung, das zuletzt durch Artikel 1 des Gesetzes vom 11. Juli 2012 (BGBI. I S.1478) geändert worden ist.

49 Prof. Dr. Alexander Hemmelrath, Dipl.-Jur. Philipp Kepper; „Die Bedeutung des Authorized OECD Approach ( $A O A$ ) für die deutsche Abkommenspraxis". IStR 2013, pp.39-40.

50 BFH v. 9.2.2011, I R 54, 55/10, IstR 2011, 345; v. 25.5.2011, I R 95/10, IstR 2011, 688, Tz. 19. 
this moment onwards, states should have been aware of the consequences of concluding a DTC with Germany, which implies the acceptance of the application of the AOA in their bilateral agreements. Generally, however, it should be concluded that the AOA can only be applied under DTCs when Germany and the other party to the DTC explicitly agreed on the application of the AOA according to the new version of Article 7 of the OECD Model Tax Convention. However, practical experience proves that this results in legal uncertainty, which complicates the attribution of profits to PEs.

\section{Conclusion}

The AOA was implemented in §1 para.5 AStG and follows the same twostep approach as in the new version of Article 7 of the 2010 OECD Model Tax Convention. It is doubtful, however, whether the AStG was the right tax act to implement the AOA in. Furthermore, it is not even clear, whether it was necessary to implement the AOA in German national law at all, due to the fact that there only is a legislative gap in case of profit attributions to taxable persons subject to unlimited tax liability. The AOA results in large complications for the attribution of profits to PEs under German tax law. Due to the existing uncertainties concerning definitions of certain terms, the application of the AOA is not clear in practice. It is of utmost importance to achieve a higher level of legal certainty in order to ensure an efficient application of the AOA under German law. This shows that there are numerous open questions that still have to be solved by the legislator in the near future. But even if German law is perfectly clear on how to apply the AOA there will still be international discrepancies. Different states have different ideas on how to implement the AOA into their respective national laws. Even though the OECD intended to harmonize the rules on the profit attributions to PEs, this will be very difficult to achieve under the AOA, given the still existing differing rules across the OECD countries. Different applications of the AOA can give rise to double taxation or double non-taxation respectively, which is the opposite of what the OECD as well as the OECD countries try to achieve when they negotiate and conclude DTCs.

Therefore, it is difficult to predict, how Germany will implement the AOA in future DTCs with other states. The assumption that Germany still does not fully agree to the application / is not perfectly clear on how to apply the AOA can be derived from the fact that Germany still concluded DTCs containing the old methods for the profit attribution to PEs even after the AOA has officially been introduced in the OECD Model Tax Convention 2010 and after the AOA had been implemented in $\S 1$ para. 5 
AStG. The fact that the AOA was not accepted by the United Nations as well as that it was not supported by all OECD countries indicates that there is no international consensus on the application of the AOA or a common method of how to apply profits to PEs respectively, which weakens the AOA and its application.

According to German law, the AOA cannot be applied with retrospective effect. In order to be able to apply the AOA, both parties to a DTC have to give their consent to the application of the AOA in their bilateral cooperations. This is due to the fact that states should not be bound by rules they were not aware of at the time they concluded the relevant DTC. German case law as well as constitutional law clearly underline the fact that the static approach of interpretation should prevail over a dynamic approach of interpretation, meaning that the AOA can only be applied once it has actually been implemented in a DTC. However, there are doubts concerning the application of the AOA to DTCs that were concluded after 2008, when the rules on the AOA had partly been implemented into the OECD report on the attribution of profits to PEs and the Commentary on the OECD Model Tax Convention already. Although this could be considered as an implicit agreement to the application of the AOA, it would be more reasonable if it was still required that the parties explicitly agreed to the application of the AOA and implemented the approach in the text of the DTC itself. It would be unreasonable to be bound by the Commentary on the OECD Model Tax Convention when the DTC concluded between Germany and the other state does not explicitly refer to the AOA as the method to be applied to attribute profits to PEs. Therefore, the AOA cannot and should not be applied to already existing DTCs, not including the approach of Article 7 OECD Model Tax Convention 2010, with retrospective effect. Accordingly, we are currently facing an intermediary phase, which complicates the choice for the correct method to attribute profits to PEs. As long as Germany does not find a clear cut rule on how to attribute profits to PEs the above mentioned problems will continue to exist. Therefore, the legislator should aim at overcoming the difficulties arising in the context of the application of the AOA under German national tax law. 